\title{
SCAFFOLDING DALAM PEMBELAJARAN FISIKA BERBASIS PROBLEM BASED INSTRUCTION (PBL): EFEKNYA TERHADAP PEMAHAMAN KONSEP DAN SELF EFFICACY
}

\section{SCAFFOLDING IN PHYSICS LEARNING BASED ON PROBLEM BASED INSTRUCTION (PBL): THE EFFECT ON CONCEPT UNDERSTANDING AND SELF EFFICACY}

\author{
Rahma Diani ${ }^{1}$, Husnul Khotimah ${ }^{2}$, Uswatun Khasanah $^{3}$, Muhammad Ridho Syarlisjiswan ${ }^{4}$ \\ ${ }^{1,2}$ Prodi Pendidikan Fisika Fakultas Tarbiyah dan Keguruan Universitas Islam Negeri Raden Intan \\ Lampung \\ ${ }^{3}$ Prodi Pendidikan Agama Islam Fakultas Tarbiyah dan Keguruan Universitas Islam Negeri Raden Intan \\ Lampung \\ ${ }^{4}$ Program Pascasarjana Universitas Sebelas Maret Surakarta \\ E-mail: rahmadiani@radenintan.ac.id
}

Diterima: 17 Agustus 2019. Disetujui: 16 Oktober 2019. Dipublikasikan: 29 November 2019

\begin{abstract}
In physics learning a learning is needed which in addition to increasing understanding of concepts can also improve students' self-efficacy, one by one using the PBL model with scaffolding. With scaffolding, educators can provide assistance in stages to students who experience difficulties in learning. The purpose of this study was to determine the effects of PBL-based physics learning and scaffolding on understanding concepts and self efficacy. This type of research is the Quasy experiment using a non equivalent control group design. The research was conducted at one of the high schools in Bandar Lampung. The sampling technique is purposive sampling. The instrument used to measure understanding of the concept is a three-tier diagnostic test consisting of 10 questions, while the instrument for measuring self-efficacy is the observation sheet. From this study, the results showed that PBL-based physics learning with scaffolding was effective against the understanding of concepts and the self-efficacy of students. The value of the effect size obtained is 1.29 with a high category.
\end{abstract}

Keywords: PBL, concept understanding, physics learning, scaffolding, self efficacy

Abstrak: Dalam pembelajaran fisika dibutuhkan suatu pembelajaran yang selain dapat meningkatkan pemahaman konsep juga dapat meningkatkan self efficacy peserta didik, salah satungan dengan menggunakan model PBL dengan scaffolding. Dengan scaffolding, pendidik dapat memberikan bantuan secara bertahap kepada peserta didik yang mengalami kesulitan dalam pembelajaran. Tujuan penelitian ini adalah untuk mengetahui efek dari pembelajaran fisika berbasis PBL dengan scaffolding terhadap pemahaman konsep dan self efficacy. Jenis penelitian adalah Quasy experiment menggunakan desain non equivalent control group. Penelitian dilaksanakan pada salah satu SMA di Bandar Lampung. Teknik pengambilan sampel adalah purposive sampling. Instrumen yang digunakan untuk mengukur pemahaman konsep adalah three-tier test diagnostic yang terdiri atas 10 soal, sedangkan instrumen untuk mengukur self efficacy adalah lembar observasi. Dari penelitian ini diperoleh hasil bahwa pembelajaran fisika berbasis PBL dengan scaffolding efektif terhadap pemahaman konsep serta self efficacy peserta didik. Nilai effect size yang diperoleh adalah 1,29 dengan kategori tinggi.

\section{(C) 2019 Unit Riset dan Publikasi Ilmiah FTK UIN Raden Intan Lampung}

Kata Kunci: PBL, pemahaman konsep, pembelajaran fisika, scaffolding, self efficacy 


\section{PENDAHULUAN}

Pada hakikatnya tujuan pembelajaran fisika adalah untuk menghantarkan peserta didik dalam menguasai konsep-konsep yang diperoleh dari buku, media pembelajaran atau alam sekitar (Sari, Suyanto, \& Suana, 2017), (Mubarrok \& Mulyaningsih, 2014). Pemahaman konsep merupakan kemampuan peserta didik dalam menguasai materi baik rumus maupun teori yang kemudian dapat diubahnya dalam bentuk yang lebih mudah dipahami (Puspitasari, 2017), (Putra, Sujarwanto, \& Sekar, 2018). Pemahaman konsep menjadi salah satu kunci keberhasilan dalam mempelajari sains khususnya Fisika, sehingga tidak harus menghafal rumus tetapi cukup dengan memahami konsep nya (Elisa, Mardiyah, \& Ariaji, 2017).

Hasil prapenelitian yang dilakukan kepada peserta didik salah satu SMA di Bandar Lampung menunjukkan bahwa pemahaman konsep peserta didik pada materi suhu dan kalor masih rendah. Rendahnya pemahaman konsep peserta didik disebabkan karena pembelajaran yang diterapkan guru masih bersifat teacher centered. Guru hanya menyampaikan materi pembelajaran secara satu arah. Peserta didik hanya dilibatkan dalam mencontohkan saja. Namun hanya sedikit contoh yang diidentifikasi. Aktivitas belajar peserta didik menjadi tidak bervariasi, hanya mendengarkan informasi dari guru saja. Diakui peserta didik, bahwa pembelajaran tersebut membuat motivasi belajar rendah.

Masalah lain yang ditemukan adalah rendahnya self efficacy peserta didik. Self efficacy merupakan keyakinan seseorang terhadap kemampuannya dalam menyelesaikan suatu masalah guna mencapai suatu hasil tertentu yang diharapkan (Lela, Herkulana, \& Aminuvati, 2014), (Adicondro \& Purnamasari, 2011). Self efficacy adalah kunci dasar yang dimiliki seseorang terhadap apa yang dilakukan (Novferma, 2016). Rendahnya self efficacy juga merupakan dampak dari pembelajaran teacher centered yang diterapkan guru. Peserta didik tidak dilatih untuk meningkatkan kepercayaan terhadap kemampuan diri sendiri sehingga selalu bergantung kepada orang lain. Self efficacy berpengaruh terhadap prestasi belajar dan keberhasilan dalam menyelesaikan suatu tugas tertentu serta sebagai pemecah masalah yang baik (Rustika, 2012), (Jatisunda, 2017). Semakin tinggi self efficacy peserta didik akan dapat mengatasi tantangan ataupun hambatan dan dapat meningkatkan performa dalam bidang akademik (Manafe, Setyosari, Kuswandi, \& Ulfa, 2016), (Shofiah \& Raudatussalamah, 2014) (Sunaryo, 2017), (Islami, Nahadi, \& Permanasari, 2015), begitupula sebaliknya. (Sujarwo,2014), (Fitri,
2017), (Yuliarti, Khanafi, \& Putra, 2016). Self efficacy tidak datang dengan sendirinya melainkan muncul dari pengamalam sendiri, pengalaman orang lain, nasihat orang lain dan berbagi ilmu pengetahuan (Hidayat, 2015). Dengan demikian guru dituntut untuk mencipatakan pembelajaran yang dapat mengatasi permasalahan ini, misalnya melalui penmiliham model dan strategi pembelajaran yang tepat.

Model pembelajaran PBL merupakan model pembelajaran yang menggunakan permasalahan nyata yang ditemukan untuk memperoleh pengetahuan (Diani, Saregar, \& Ifana, 2016). Model ini menuntut peserta didik untuk mendapatkan pengetahuan, membuat peserta didik dapat memecahkan masalah, dan memiliki keterampilan untuk berpartisipasi dalam kegiatan kelompok (Diani, Yuberti, \& Syarlisjiswan, 2018), (Desriyanti \& Lazulva, 2016). Keunggulan dari pembelajaran berbasis masalah yaitu 1) pemecahan masalah cukup bagus untuk memahami pelajaran, 2) pemecahan masalah berlangsung selama proses pembelajaran menantang kemampuan peserta didik dan memberikan kepuasan, 3) dapat meningkatkan aktivitas belajar 4) mengembangkan pengendalian diri peserta didik, 5) mengembangkan kemampuan memecahkan masalah peserta didik, 6) merangsang peserta didik untuk belajar secara kontinu. (bekti ,2013), (eviyanti,2017).

Scaffolding didasarkan pada teori Vygotsky (Rahayuningsih \& Qahar, 2014) bahwa pembelajaran terjadi apabila peserta didik belajar menangani tugas-tugas yang belum dipelajari namun tugas itu masih berada dalam jangkauan kemampuan atau tugas tersebut berada dalam Zona of Proximal Development (ZPD) (Buyung \& Dwijanto, 2017). Menurut Vygostky tingkat perkembangan kemampuan peserta didik berada pada dua level atau tingkatan, yaitu tingkatan kemampuan aktual (yang dimiliki peserta didik) dan kemampuan tingkat kemampuan potensial (yang dikuasai peserta didik) (Septriani, Irwan, \& Meira, 2014). Zona antara tingkat aktual dan potensial itu disebut dengan zone of proximal development (ZPD) (Sidin, 2016). Strategi pembelajaran scaffolding merupakan interaksi pendidik dan peserta didik dengan tujuan membantu peserta didik yang mengalami kesulitan (Badriyah, Rahman, \& Susanto, 2017). Bantuan yang diberikan secukupnya pada peserta didik yang mengalami kesulitan (Chairani, 2015). Pemberian bantuan ini bertujuan untuk mengurangi kebebasan peserta didik dalam mengerjakan tugas sehingga lebih fokus pada pemahaman yang dirasa sulit (Rahmatiah, H, \& Kusairi, 2016). 
Pemberian bantuan tersebut diberikan secara bertahap dan secara perlahan dikurangi (Ashari, Salwah, \& A, 2016). Beragam bentuk scaffolding yang dapat digunakan diantaranya scaffolding konseptual, verbal, visual dan pengambilan keputusan (Haniin, Diantoro, \& H, 2015). Scaffolding menjadi salah satu strategi yang baik untuk diterapkan di kelas (Lestari, 2016).

Pembelajaran fisika dengan menggunakan model PBL dengan scaffolding dirasa dapat mengatasi rendahnya pemahaman konsep dan self efficacy peserta didik pada pembelajaran fisika. Berdasarkan penelitian-penelitian yang sudah dilakukan dapat diketahui bahwa penerapan scaffolding dalam proses pembelajaran dapat membantu peserta didik dalam meningkatkan pengetahuan (Badriyah et al., 2017). Selanjutnya pembelajaran menggunakan scaffolding dapat meningkatkan prestasi belajar lebih tinggi (Rahmatiah et al., 2016). Penerapan scaffolding juga dapat mendorong aktifitas serta motivasi belajar sehingga dapat meningkatkan pemahaman konsep peserta didik (Qamar \& Riyadi, 2016). Kemudian penelitian menggunakan model PBL dapat mengembangkan kemampuan peserta didik dalam belajar (Manrulu \& Sari, 2015) serta dapat meningkatkan kemampuan berpikir tingkat tinggi dalam memecahkan masalah (Jayanti, Romlah, \& Saregar, 2016). Penelitian ini mempunyai perbedaan dari penelitian-penelitian sebelumnya menggunakan model pembelajaran PBL dalam proses pembelajaran dimana di dalamnya terdapat strategi scaffolding untuk meningkatkan pemahaman konsep dan self efficacy peserta didik.

\section{METODE PENELITIAN}

Penelitian ini merupakan penelitian Quasy eksperiment (Sanjaya, 2015) dengan desain yang digunakan yaitu non equivalent group (Setyosari, 2015). Penelitian dilaksanakan pada salah satu SMA di Bandar Lampung, sampel (kelas eksperimen dan kelas kontrol) ditentukan dengan tehknik perposive sampling (Arikuntoro, 2013).

Instrumen yang digunakan untuk mengukur pemahaman konsep adalah tes berupa soal dengan bentuk three-tier test (Silviani, Muliyani, \& Kurniawan, 2017). Pada tes ini peserta didik bukan hanya mengerjakan soal berupa konsep-konsep tetapi juga mengungkapkan alasan dari memilih jawaban serta memilih tingkat keyakinan terhadap pilihan soal pada tingkat pertama dan kedua (Kirbulut, 2014), (Anintia, Sadhu, \& Annisa, 2017). Jenis tes ini dapat mengungkapkan kemampuan pemahaman peserta didik lebih detail, mana yang sudah paham konsep, kurang paham konsep, tidak paham konsep dan miskonsepsi (Jumini, Retyanto, \& Noviyanti,), (Ekawati \& Sukmawati, 2017), (Cheung \& Yang, 2018). Three-tier test dapat mempermudah serta tidak membutuhkan waktu banyak untuk mengidentifikasi pemahaman konsep (Putri, 2016). Tes terdiri atas 10 soal yang sudah di uji validitas, reliabilitas, tingkat kesukaran, daya pembeda dan uji pengecoh. Penskoran pemahaman konsep terdapat pada tabel 1

Tabel 1. Penskoran Tingkat Pemahaman Konsep dengan Three-tier Test Diagnostic

\begin{tabular}{ccc}
\hline No & Pola jawaban & Kategori \\
\hline 1 & $\begin{array}{c}\text { Benar + Benar } \\
+ \text { Yakin }\end{array}$ & Paham konsep \\
\hline 2 & $\begin{array}{c}\text { Benar + Benar } \\
+ \text { tidak yakin }\end{array}$ & $\begin{array}{c}\text { Kurang paham } \\
\text { konsep }\end{array}$ \\
\hline 3 & Salah + Salah +Yakin & $\begin{array}{c}\text { Tidak paham } \\
\text { konsep }\end{array}$ \\
\cline { 1 - 2 } 4. & $\begin{array}{c}\text { Salah + Benar } \\
+ \text { Tidak yakin }\end{array}$ & Menebak \\
\cline { 2 - 3 } & $\begin{array}{c}\text { Benar + Salah } \\
+ \text { Tidak Yakin }\end{array}$ & \\
\hline \multirow{3}{*}{5} & Benar + Salah +yakin & Miskonsepsi \\
\cline { 2 - 2 } & Salah + Salah +Yakin & \\
\hline
\end{tabular}

(Mulyastuti, Setyarsih, \& Mukhayyarotin, 2016), (Putri, 2016), (Silviani et al., 2017).

Ukuran Tingkat keyakinan yang digunakan yaitu menggunakan certain of response index CRI.

Tabel 2. Kategori Skala Tingkat Keyakinan CRI

\begin{tabular}{ccc}
\hline Kategori & Skala & Tingkat keyakinan \\
\hline Menebak & 0 & \\
Sangat tidak yakin & 1 & Rendah/tidak yakin \\
Tidak yakin & 2 & \\
\hline Kurang Yakin & 3 & \\
yakin & 4 & Tinggi/yakin \\
Sangat yakin & 5 & \\
\hline
\end{tabular}

(Hasan, Bagayoko, Kelly, 2014)

Instrumen lain yang digunakan adalah lembar observasi untuk mengetahui self efficacy peserta didik. Analisis angket self efficacy mengacu pada tabel 3.

Tabel 3. Penskoran self efficacy

\begin{tabular}{|c|c|c|c|}
\hline No & Skor & Kriteria & Keterangan \\
\hline 1 & $91-100$ & $\begin{array}{l}\text { Sangat } \\
\text { tinggi }\end{array}$ & $\begin{array}{c}\text { Penuh rasa percaya } \\
\text { diri }\end{array}$ \\
\hline 2 & $78-90$ & Tinggi & Rasa percaya tinggi \\
\hline 3 & $65-77$ & $\begin{array}{l}\text { Cukup } \\
\text { tinggi }\end{array}$ & $\begin{array}{c}\text { Rasa percaya cukup } \\
\text { tinggi }\end{array}$ \\
\hline 4 & $52-64$ & Sedang & $\begin{array}{c}\text { Rasa percaya diri } \\
\text { sedang }\end{array}$ \\
\hline 5 & $39-51$ & $\begin{array}{l}\text { Cukup } \\
\text { rendah }\end{array}$ & $\begin{array}{l}\text { Rasa percaya diri } \\
\text { cukup rendah }\end{array}$ \\
\hline 6 & $26-38$ & Rendah & $\begin{array}{l}\text { Rasa percaya diri } \\
\text { rendah }\end{array}$ \\
\hline 7 & $14-25$ & $\begin{array}{l}\text { Sangat } \\
\text { rendah }\end{array}$ & Tidak percaya diri \\
\hline
\end{tabular}

(Sunaryo, 2017) 
Analisis data yang dilakukan adalah uji normalitas yang digunakan untuk mengetahui sampel yang digunakan dalam penelitian normal atau tidak normal. Jika $\mathrm{L}_{\text {hitung }}<\mathrm{L}_{\text {tabel }}$ dengan $\alpha=0,05$, maka data berdistribusi normal, dan jika $\mathrm{L}_{\text {hitung }}>\mathrm{L}_{\text {tabel }}$ maka data tidak berdistribusi normal (Saregar, Latifah, \& Sari, 2016). Uji homogenitas digunakan untuk melihat kesamaan antara dua keadaan. Jika $\mathrm{F}_{\text {hitung }}<\mathrm{F}_{\text {tabel }}$ dengan $\alpha=0,05$ maka data tersebut homogen, dan jika $F_{\text {hitung }}>F_{\text {tabel }}$ maka tidak homogen (Sugiyono, 2015). Uji hipotesis (uji-t). Jika data berdistribusi normal dan homogen maka dilakukan uji-t, adapun hipotesis dalam penelitian ini adalah Jika $\mathrm{T}_{\text {hitung }}<\mathrm{T}_{\text {tabel }}$ maka tidak terdapat pengaruh dan jika $T_{\text {hitung }}>T_{\text {tabel }}$ maka terdapat pengaruh. Selanjutnya Uji N-Gain digunakan untuk mengetahui ada atau tidaknya peningkatan pada pemahaman peserta didik, dicari dengan menggunakan persamaan:

$$
\mathrm{N}-\text { Gain }(\mathrm{g})=\frac{\text { \%posttest }-\% \text { pretest }}{100-\text { skorpretest }}
$$

dimana jika nilai Gain $\geq 0,7$ (tinggi), jika gain $0,7>\mathrm{g} \geq 0,3$ (sedang) dan jika gain $<0,3$ (rendah) (Hake, 1999).

Uji effect size digunakan untuk mengetahui besarnya efek suatu variabel pada variabel lain. Untuk mengujinya menggunakan persamaan dibawah ini: (Diani, Yuberti, \& Syafitri, 2016), (Saregar, Diani, \& Kholid, 2017)

$$
d=\frac{m_{A}-m_{B}}{\left[\left(s d_{A}^{2}+s d_{B}^{2}\right) / 2\right]^{1 / 2}}
$$

Dimana jika $\mathrm{d}<0,2$ (kecil), jika0,2<d<0,8 (sedang) dan jika $\mathrm{d}>0,8$ (tinggi) (Saregar et al., 2016).

\section{HASIL DAN PEMBAHASAN}

\section{Penerapan Scaffolding dalam Pembelajaran Berbasis PBL Terhadap Pemahaman Konsep Peserta Didik}

Hasil pemahaman konsep kelas eksperimen dan kelas kontrol disajikan pada Gambar 1.

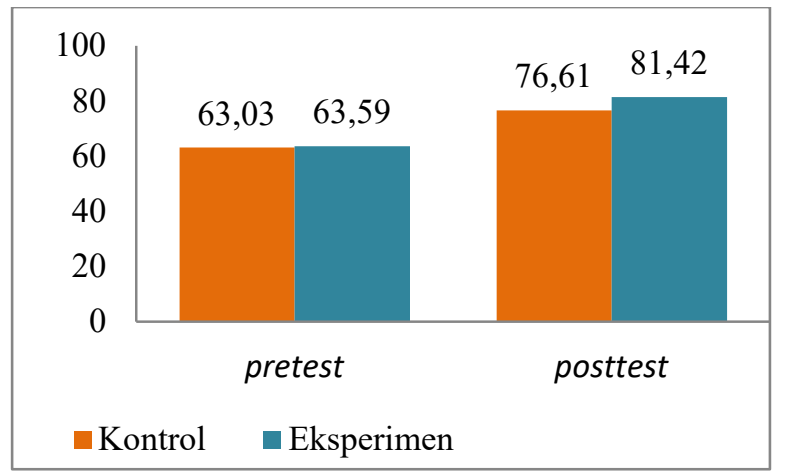

Gambar 1. Rata-rata Hasil Pretest dan Postest

Berdasarkan hasil pretest dan postest yang diperoleh diketahui bahwa nilai posttest lebih besar dari pretest artinya terdapat peningkatan sebelum dan sesudah diberikannya perlakuan, dan nilai tertinggi berada pada kelas esperimen. Terdapat tujuh indikator dalam pemahaman konsep yaitu menafsirkan, mencontohkan, mengklasifikasi, merangkum, menyimpulkan, membandingkan dan menjelaskan (Anderson \& Krathwohl, 2001). Adapun rincian pemahaman konsep untuk masing-masing indikator pembelajaran disajikan pada Tabel 4.

Tabel 4. Rata-rata Persentase Pemahaman Konsep untuk Masing-masing Indikator Pembelajaran

\begin{tabular}{clc}
\hline No Soal & \multicolumn{1}{c}{ Indikator } & Rata-rata presentase \\
\hline 1 & Menjelaskan faktor yang mempengaruhi pemuaian & $97,2 \%$ \\
2 & Mengklasifikasikan faktor yang mempengaruhi & $77,8 \%$ \\
& perpindahan kalor secara konduksi & \\
3 & Menentukan perbandingan suhu & $97,2 \%$ \\
4 & Memberikan contoh tentang perubahan wujud mencair & $100 \%$ \\
5 & Menjelaskan tentang Asas Black & $52,8 \%$ \\
6 & Menjelaskan penerapan radiasi pada api unggun & $80,6 \%$ \\
7 & Menentukan tekanan gas suatu zat & $94,4 \%$ \\
8 & Menjelaskan persamaan yang digunakan pada muai & $91,7 \%$ \\
9 & panjang & $88,89 \%$ \\
& Menjelaskan perbedaan radiasi yang terjadi ketika & \\
& menggunakan baju warna hitam dan putih pada siang & $88,9 \%$ \\
\hline
\end{tabular}

Hasil Rekapitulasi presentase rata-rata pemahaman konsep peserta didik dilakukan dengan tujuan melihat gambaran secara keseluruhan mengenai butir-butir soal pada konsep suhu dan kalor. Berdasarkan Tabel 4 diketahui bahwa pemahaman konsep peserta didik pada setiap indikator soal sudah cukup tinggi. Berdasarkan Tabel 4 terlihat pula bahwa pemahaman konsep tertinggi terjadi pada indikator keempat, sedangkan pemahaman konsep terendah terjadi pada indikator kelima.

Data yang diperoleh kemudian dianalisis. Adapun hasil uji normalitas dan homogenitas data disajika pada Tabel 5 dan Tabel 6 . 
Tabel 5. Hasil Uji Normalitas Pretest dan Posttes Kelas Eksperimen dan Kontrol

\begin{tabular}{ccccc}
\hline Statistik & \multicolumn{3}{c}{ Eksperimen } & \multicolumn{2}{c}{ Kontrol } \\
\cline { 2 - 5 } & Pretest & posttest & Pretest & posttest \\
$\mathrm{L}_{\text {hitung }}$ & 0.144 & 0.167 & 0.197 & 0.95 \\
$\mathrm{~L}_{\text {tabel }}$ & 1.68 & 1.68 & 1.68 & 1.68 \\
Keterangan & & Normal & & Normal \\
\hline \multicolumn{6}{c}{ Tabel 6. Hasil uji homogenitas pretest posttes kelas eksperimen Dan kontrol } \\
\hline Statistik & Pretest & posttest & Keterangan \\
\hline $\mathrm{F}_{\text {hitung }}$ & 1.296 & 1.131 & Homogen \\
$\mathrm{F}_{\text {tabel }}$ & 1.66 & 1.66 & Homogen \\
\hline
\end{tabular}

Berdasarkan Tabel 5 dan 6 diketahui bahwa diperoleh data normal yaitu $\mathrm{L}_{\text {hitung }}<\mathrm{L}_{\text {tabel }}$ dan homogen $\mathrm{F}_{\text {hitung }}<\mathrm{F}_{\text {tabel }}$, karena data normal dan homogen maka dilakukan uji-t. Adapun hasil yang diperoleh disajikan pada Tabel 7

\begin{tabular}{ccc}
\multicolumn{3}{c}{ Tabel 7. Hasil uji Hipotesis } \\
\hline $\mathbf{T}_{\text {hitung }}$ & $\mathbf{T}_{\text {tabel }}$ & Keputusan uji \\
\hline 2,32 & 1,66 & Ho ditolak \\
\hline
\end{tabular}

Berdasarkan tabel 7 diketahui bahwa $\mathrm{T}_{\text {hitung }}>$ $\mathrm{T}_{\text {tabel }}$ dengan demikian $\mathrm{H}_{1}$ diterima dan $\mathrm{H}_{\mathrm{o}}$ ditolak sehingga terdapat pengaruh penerapan scaffolding dalam pembelajaran berbasis $\mathrm{PBL}$ terhadap pemahaman konsep peserta didik.
Adapun hasil uji N-Gain yang diperoleh disajikan pada Tabel 8

\begin{tabular}{ccc}
\multicolumn{3}{c}{ Tabel 8. Hasil Uji N-Gain } \\
\hline Uji & Eksperimen & Kontrol \\
\hline N-Gain & 0,569775 & 0,36381 \\
Kategori & Sedang & Sedang \\
\hline
\end{tabular}

Berdasarkan tabel 8 diketahui bahwa nilai NGain dalam kategori sedang

Uji effect size merupakan ukuran seberapa besarnya tingkat pengaruh suatu faktor terhadap faktor lainnya. (Saregar et al., 2016) Berikut adalah hasil uji effect size.

Tabel 9. Hasil Effect Size

\begin{tabular}{lcccc}
\hline \multicolumn{1}{c}{ Kelas } & Rata-rata N-Gain & Standar Deviasi & effect size & Keterangan \\
\hline Eksperimen & 19,65 & 4,147 & 1,29 & \multirow{2}{*}{ Tinggi } \\
Kontrol & 1,61 & 5,122 & 1,29 & \\
\hline
\end{tabular}

Berdasarkan hasil data pada Tabel 9 diketahui bahwa hasil uji effect size diperoleeh 1,29 dengan kategori tinggi dengan demikian penerapan scaffolding dalam pembelajaran berbasis PBL efektif terhadap pemahaman konsep peserta didik.

\section{Penerapan Scaffolding dalam Pembelajaran Berbasis PBL Terhadap Self Efficacy}

Adapun hasil self efficacy peserta didik disajikan pada Gambar 2. Self efficacy yang diteliti merujuk pada 3 dimensi yaitu magnitude, generality dan strenght (Almira, Samantha, \& Rozali, 2016).

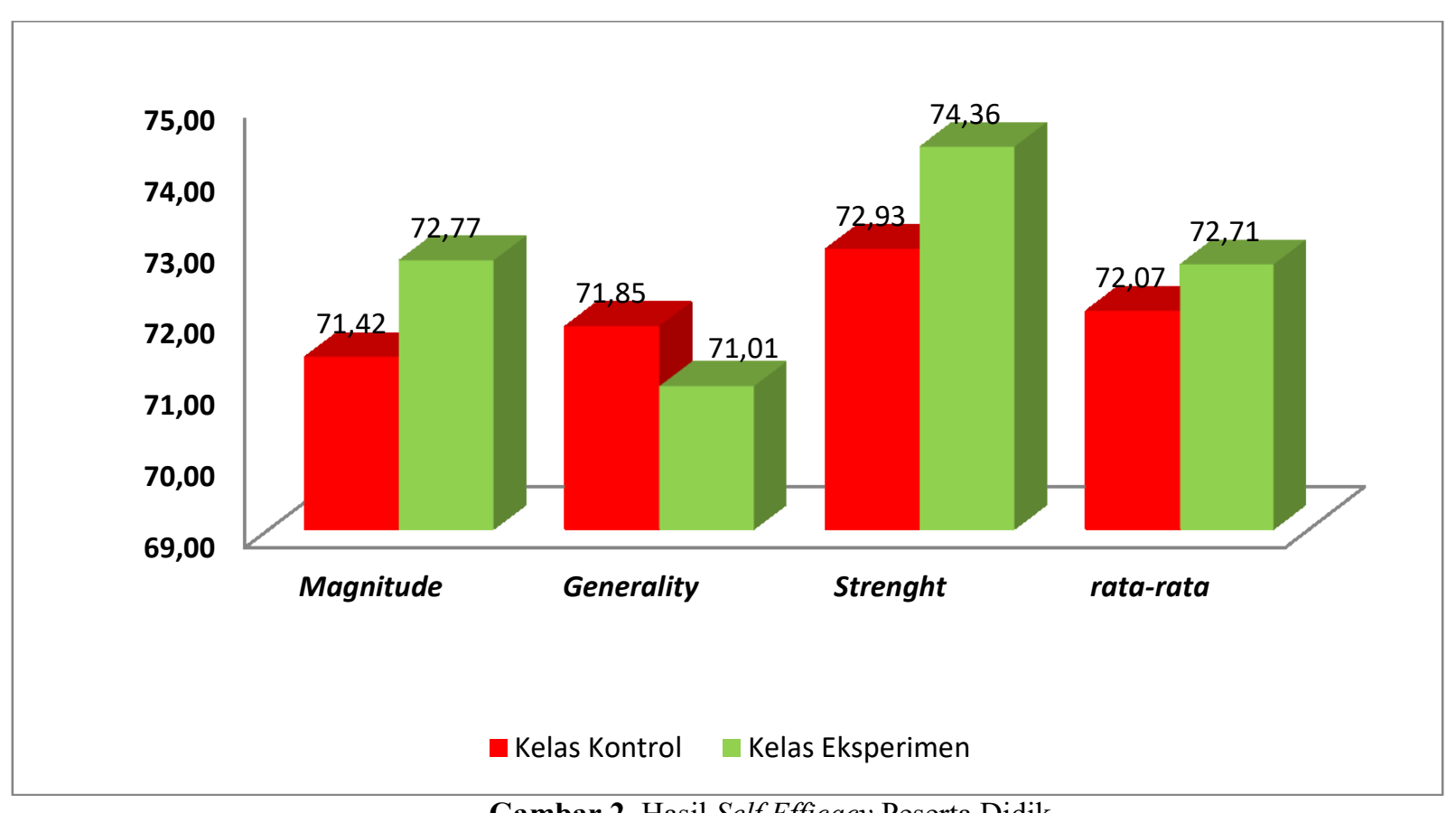

Gambar 2. Hasil Self Efficacy Peserta Didik 
Berdasarkan gambar 3 diketahui bahwa rata-rata self efficacy peserta didik kelas eksperimen lebih tinggi dibandingkan dengan kelas kontrol. Dengan demikian penerapan scaffolding dalam pembelajaran berbasis PBL efektif terhadap self efficacy peserta didik.

Pemahaman konsep peserta didik meningkat pada saat posttest setelah diberikannya perlakuan, artinya model dan strategi pembelajaran yang digunakan pada proses pembelaran berpengaruh terhadap pemahaman konsep peserta didik, model PBL dapat meningkatan pemahaman konsep karena model tersebut menuntut peserta didik untuk mendapatkan pengetahuan yang lebih dengan memberikan suatu permasalahn dan kemudian memecahkan masalahnya (Diani et al., 2018). Langkah-langkah model ini antara lain (1) orientasi peserta didik pada masalah, mengorganisasikan peserta didik untuk belajar, (3) membimbing penyelidikan individu maupun kelompok, mengembangkan hasil karya, dan (5) menganalisis dan mengevaluasi proses pemecahan masalah (Jayanti et al., 2016). Pemilihan model dan strategi yang dapat meningkatkan pemahaman konsep dan self efficacy sangat diperlukan karena dapat memberikan hasil belajar yang baik. Model PBL dapat meningkatkan pemahaman konsep karena dalam model tersebut meminta agar peserta didik dapat memecahkan masah yang ada yang sesuai dengan literatur sehingga peserta didik berfikir serta belajar memahaminnya (Desriyanti \& Lazulva, 2016).

Pada saat peserta didik mengalami kesulitan maka perlu adanya scaffolding (bimbingan) (Haniin et al., 2015). Scaffolding tersebut bertujuan untuk membantu peserta didik yang mengalami kesulitan sehingga jika diberikan bantuan dan bimbingan dapat menyelesaikan suatu permasalahan yang ada hal tersebut dapat membuat peserta didik paham terhadap suatu konsep tertentu, bantuan akan dikuragi seiring dengan meningkatnya pengetahuan peserta didik (Rusli \& Widodo, 2014). Langkah-langkah scaffolding diantaranya adalah 1) mengecek pengetahuan sebelumnya yang dimiliki peserta didik, 2) menentukan the zone of proximal (ZPD), 3) merancang tugas-tugas belajar, 4) memantau aktivitas dalam belajar, dan 5) mengecek dan mengevaluasi belajar (Ashari et al., 2016).

Bantuan yang diberikan berupa probing promting untuk mengembangkan pengetahuan peserta didik, memberian umpan balik, memberikan contoh, membantu peserta didik menarik kesimpulan, bantuan disajikan dengan serangkaian pertanyaan yang sifatnya menuntun dan menggali pengetahuan yang dimiliki dengan yang akan dipelajari (Septriani et al., 2014). Selain itu bantuan yang diberikan berupa 1) Question untuk melihat pemahaman peserta didik, 2) promting untuk memfasilitasi kognisi peserta didik, 3) cueng untuk mengalihkanperhatian peserta didik untuk lebih fokus terhadap informasi yang diberikan, 4) eksplaining untuk peserta didik yang belum memiliki pengetahuan yang cukup untuk menyelesaikan tugas (Qamar \& Riyadi, 2016).

Selain pemahaman konsep, Self efficacy juga dibutuhkan oleh peserta didik, karena self efficacy berpengaruh terhadap hasil belajar peserta didik (Jatisunda, 2017) dimana Self efficacy yang tinggi berpengaruh terhadap peforma akademik (Islami et al., 2015), dengan demikian sangat dibutuhkan self efficacy yang tinggi dalam diri. Karena jika memiliki self efficacy rendah maka dapat menurunkan peforma akadmik (Fitri, 2017) (Sujarwo, 2014).

Dengan adanya bimbingan belajar dalam proses pembelajaran dapat meningkatkan kepercayaan peserta didik, karena peserta didik akan lebih luas bertanya terkait hal yang belum dipahami dan yang dianggapnya sulit, yang kemudian diberikan bimbingan secara 
bertahap bagaimana memecahkan masalah yang ada. Ketika peserta didik mulai memahami maka secara perlahan bimbingan tersebut dikurangi (Ashari et al., 2016) sehingga membuat peserta didik percaya diri bahwa dirinya mampu menyelesaikan permasalahan yang ada. Scaffolding (bantuan) yang diberikan pada saat peserta didik mengalami kesulitan pada level magnitude, generality dan strenght yaitu scaffolding motivasi, motivasi strategi, metakognitif dan konseptual (R.Belland, 2017) diberikan berdasarkan permasalahan yang dihadapi peserta didik kemudian bantuan yang diberikan juga berupa scafffolding tertulis, lisan, visual atau pengambilan keputusan (Haniin et al., 2015).

\section{KESIMPULAN}

Berdasaran hasil penelitian yang telah dilakukan maka dapat disimpulkan bahwa terdapat scaffolding dalam pembelajaran fisika berbsis PBL efektif terhadap pemahaman konsep dan self efficacy peserta didik pada materi suhu dan kalor. Nilai effect size yang diperoleh adalah 1,29 dengan kategori tinggi.

\section{DAFTAR PUSTAKA}

Adicondro, N., \& Purnamasari, A. (2011). Efikasi diri, Dukungan Sosial Keluarga dan Self Regulated Learning pada Siswa Kelas VIII. Humanitas, VIII(1), 19.

Almira, R., Samantha, E., \& Rozali, Y. A. (2016). HUBUNGAN SELF EFFICACY DENGAN PRESTASI BELAJAR PADA PESERTA MATA KULIAH TOEFL 2 ( STUDI PADA MAHASISWA ANGKATAN 2014 REGULER AKTIF DI SEMESTER GANJIL 2015 / 2016 UNIVERSITAS ESA UNGGUL ), 2.

Anderson, L. W., \& Krathwohl, D. R. (2001). Kerangka Landasan Untuk Pembelajaran, Pengajaran, dan Asesmen (Yogyakarta: Pustaka
Pelajar).

Anintia, R., Sadhu, S., \& Annisa, D. (2017). Identify Students ' Concept Understanding Using Three - Tier Multiple Choice Questions ( TTMCs ) on Stoichiometry. International Journal Of Science and Applied Science, 2(1). https://doi.org/10.20961/ijsascs.v2i1. 16734

Arikuntoro, S. (2013). Prosedur Penelitian Suatu Pendekatan Praktik. Jakarta: Rineka Cipta.

Ashari, N. W., Salwah, \& A, F. (2016). Implementas Strategi Pembelajaran Scaffolding Melalui Lesson Study Pada Mata Kuliah Analisi Real. Jurnal Matematika Dan Pendidikan Matematika, 1(1), 25.

Badriyah, L., Rahman, A., \& Susanto, H. (2017). Analisis Kesalahan dan Scaffolding Siswa Berkemampuan Rendah Dalam Menyelesaikan Operasi Tambah Kurang Bilangan Bulan. Jurnal Pendidikan: Teori Penelitian Dan Pengembangan, 2(1), 50.

Buyung, \& Dwijanto. (2017). Analisis Kemampuan Literasi Matematis melalui Pembelajaran Inkuiri dengan Strategi Scaffolding. Unnes Journal Of Mathematics Education Research, 6(1), 115.

Chairani, Z. (2015). Scaffolding dalam pembelajaran matematika 5, l(1), 39-44.

Cheung, K. L., \& Yang, D. (2018). Examining the Differences of Hong Kong and Taiwan Students Performance on the Number Sense Three-tier Test. Eurasia Journal Of Mathematics, Science Anf Technology Education, 14(7).

Desriyanti, R., \& Lazulva. (2016). Penerapan Problem Based Learning pada Pembelajaran Konsep Hidrolis Garam untuk Meningkatkan Hasil Belajar. Jurnal Tadris Kimia, 71.

Diani, R., Saregar, A., \& Ifana, A. (2016). 
Perbandingan Model Pembelajaran Problem Based Learning dan Inkuiri Terbimbing Terhadap Kemampuan Berpikir Kritis Peserta Didik. Jurnal Penelitian Pembelajaran Fisika, 7(2), 147-155.

Diani, R., Yuberti, \& Syafitri, S. (2016). Uji Effect Size Model Pembelajaran Scramble Dengan Media Video Terhadap Hasil Belajar Fisika Peserta Didik Kelas X MAN 1 Pesisir Barat. Jurnal Ilmiah Pendidikan Fisika Al-BiRuNi, 5(2).

Diani, R., Yuberti, \& Syarlisjiswan, M. R. (2018). Web-Enhanced Course Based On Problem Based Learning (PBL): Development Of Interactive Learning Media For Basic Physics II. Jurnal Ilmiah Pendidikan Fisika 'AlBiruni, $\quad$ 7(April), 107. https://doi.org/10.24042/jipfalbiruni. v7i1.2849

Ekawati, M., \& Sukmawati, S. (2017). Exploring Biology Education Students Miscontions By Using Three Tier Diagnistc Test. Proceedings.

Elisa, Mardiyah, A., \& Ariaji, R. (2017). Peningkata Pemahaman Konsep Fisika dan Aktivitas Mahasiswa Melalui Phet Simulation. Jurnal Penelitian Tindakan Kelas Dan Pengembangan Pembelajaran, 1, 15.

Fitri, I. (2017). Self Efficacy Terhadap MatematikaMelalui Pendekatan Aptitude Treatment Interaction. Jurnal Review Pembelajaran Matematika (JRPM), 2(2), 168.

Hake, R. (1999). Analyzing Change/Gain Scores. Dept. of Physics, Indiana University., 1.

Haniin, K., Diantoro, M., \& H, S. K. (2015). Pengaruh Pembelajaran TPS Dengan Scaffolding Konseptual Terhadap Kemampuan Menyelesaikan Masalah Sintesis Fisika. Jurnal Pendidikan Sains, 3(3), 99.

Hidayat, D. (2015). Teorema Dan
Aplikasi Psikologi Kepribadian Dalam Konsling (Bogor: Ghalia Indonesia).

Islami, R. A. Z. El, Nahadi, \& Permanasari, A. (2015). Hubungan Literasi Sains dan Kepercayaan Diri Siswa pada Konsep Asam Basa. Jurnal Penelitian Dan Pembelajaran IPA, 1(1), 17.

Jatisunda, M. G. (2017). Hubungan SelfEfficacy Siswa SMP dengan Kemampuan Pemecahan Masalah Matematis. Jurnal THEOREMS (The Original Research Of Mathematics), 1(2), 25-26.

Jayanti, R. D., Romlah, \& Saregar, A. (2016). Efektivitas Pembelajaran Fisika Model Problem Based Learning (PBL) Melalui Metode POE Terhadap Kemampuan Berfikir Tingkat Tinggi Peserta didik. In Seminar Nasinal Pendidikan Program Studi Pendidikan Fisika (p. 210).

Jumini, S., Retyanto, B. D., \& Noviyanti, V. (2009). Identifikasi Miskonsepsi Fisika Menggunakan Three-tier Diagnostic Test pada Pokok Bahasan Kinematika Gerak, 199.

Kirbulut, Z. D. (2014). Using Three-Tier Diagnostic Test to Asse ss Students ' Misconceptions of States of Matter. Eurasia Jurnal Of Mathematics, Science and Tchnology Education, 10(5).

https://doi.org/10.12973/eurasia.201 $4.1128 \mathrm{a}$

Lela, Y., Herkulana, \& Aminuvati. (2014). Pengaruh minat, self confidence dan self efficacy terhadap prestasi belajar kompetensi pemasaran siswa smks. Jurnal Hasil Riset, 2.

Lestari, N. F. (2016). Using Visual Scaffolding Strategy For Teaching Reading In Junior High School. ELT Perspective, 4, 132.

Manafe, Y. Y., Setyosari, P., Kuswandi, D., \& Ulfa, S. (2016). Pengaruh 
Strategi Kerjasama Kelompok dan Efikasi Diri terhadap Hasil Belajar Keterampilan Teknikal. Jurnal Pendidikan Humaniora, 4(3), 153.

Manrulu, R. H., \& Sari, D. N. (2015). Efektivis Kegiatan Lesson Study Dalam Merancang Pembelajaran Pada Mata Kuliah Gelombang Dan Optik. Al-BiRuni, 4.

Mubarrok, M. F., \& Mulyaningsih, S. (2014). Penerapan Pembelajaran Fisika pada Materi Cahaya dengan Media Phet Simulations untuk Meningkatkan Pemahaman Konsep Siswa di SMP. Jurnal Inovasi Pendidikan Fisika (JIPF), 3(1), 77.

Mulyastuti, H., Setyarsih, W., \& Mukhayyarotin. (2016). Identifikasi Peningkatan Pemahaman Konsep Siswa Materi Dinamika Rotasi Sebagai Pengaruh Penerapan Model Pembelajaran ECIRR. In proseding Semnas Pend. IPA UM (p. 258).

Novferma, N. (2016). Analisis Kesulitan dan Self Efficacy Siswa SMP dalam Pemecahan Masalah Matematika Berbentuk Soal Cerita. Jurnal Riset Pendidikan Matematika, 3(1).

Puspitasari, D. (2017). Analisis Pemahaman Konsep Siswa Tentang Elastisitas di Kelas XI SMA. In Seminar Nasional Pendidikan Fisika (Vol. 2, p. 2).

Putra, I. A., Sujarwanto, E., \& Sekar, A. (2018). Analisis pemahaman konseptual mahasiswa pada materi kinematika partikel melalui tes diagnostik. RKPFUAD, 5, 11.

Putri, A. N. (2016). Uji Coba Instrumen Three Tier Test Karya Riana Dewi Astari dalam Mngidentifikasi Miskonsepsi KonsepAtom, Ion, dan Molekul Siswa Kelas X di SMA Kolombo Sleman Tahun Ajaran 2015/2016.

Qamar, K., \& Riyadi, S. (2016). Bentuk Scaffolding dalam Pembelajaran Matematika Menggunakan Aplikasi Berbasis Teks. In Prosiding Seminar
Nasional Pendidikan Matematika (p. 302).

R.Belland, B. (2017). Instructional Scaffolding in STEM Education Strategis and Efficacy.

Rahayuningsih, P., \& Qahar, A. (2014). Analisis Kesalahan Menyelesaikan Soal Cerita Sistem Persamaan Linear Dua Variabel (SPLDV) dan Scaffolding nya Berdasarkan Analisis Kesalahan Newman pada Siswa Kelas VIII SMP Negeri 2 Malang. Jurnal Pendidikan Matematika Dan Sains, 2(2), 110.

Rahmatiah, R., H, S. K., \& Kusairi, S. (2016). Pengaruh Scaffolding Konseptual dalam Pembelajaran Group Investigation Terhadap Prestasi Belajar Fisika Siswa SMA dengan Pengetahuan Awal Berbeda, II (2), 45-54.

Rusli, M. A., \& Widodo, W. (2014). Pembelajaran Fisika melalui Pemrosesan Top Down Berbasis Scaffolding untuk Melatihkan Keterampilan Berpikir Kritis Physics Learning through Top Down Processing based on Scaffolding to Train Critical Thinking Skills. JurnalSainsmat, III(1).

Rustika, I. M. (2012). Efikasi Diri : Tinjauan Teori Albert Bandura. Buletin Psikologi, 20(1), 18.

Sanjaya, W. (2015). Penelitian

Pendidikan Jenis, Metode dan

Prosedur (3rd ed.). Jakarta: Prenadamedia Grup.

Saregar, A., Diani, R., \& Kholid, R. (2017). Efektivitas Penerapan Model Pembelajaran ATI ( Aptitude Treatment Interaction ) Dan Model Pembelajaran TAI ( Team Assisted Individualy ): Dampak Terhadap Hasil Belajar Fisika Siswa Effectiveness Of Learning Model Application ATI ( Aptitude Treatment Interaction ) And Learning Model.

Saregar, A., Latifah, S., \& Sari, M. 
(2016). Efektivitas Model Pembelajaran CUPS: Dampak Terhadap Kemampuan Berfikir Tingkat Tinggi Peserta Didik adrasah Aliyah Mathla'ul Anwar Gisting Lampung. Jurnal Pendidikan Fisika A-Biruni, $5(2)$. https://doi.org/10.24042/jpifalbiruni. v5i2.123

Sari, W. P., Suyanto, E., \& Suana, W. (2017). Analisis Pemahaman Konsep Vektor pada Siswa Sekoah Menengah Atas. Jurnal Ilmiah Pendidikan Fisika 'Al-Biruni, 6(2), 159.

https://doi.org/10.24042/jipfalbiruni. v6i2.1743

Septriani, N., Irwan, \& Meira. (2014). Pengaruh Penerapan Scaffolding Terhadap Kemampuan Pemahaman Konsep Matematika Siswa Kelas VIII SMP PERTIWI 2 Padang. Jurnal Pendidikan Matematika, 3(3), 18.

Setyosari, P. (2015). Metode Penelitian Pendidikan dan Pengembangan (4th ed.). Jakarta: Prenadamedia Grup.

Shofiah, V., \& Raudatussalamah. (2014). Self- efficacy dan Self Regulation Sebagai Unsur Penting dalam Pendidikan Karakter. Jurnal Penelitian Sosial Keagamaan, 220.

Sidin, U. S. (2016). Penerapan Strategi Scaffolding pada Pembelajaran Pemograman Web di SMK Wirabuana 1. Jurnal Publikasi Pendidikan, VI(3), 189.

Silviani, Gr., Muliyani, R., \& Kurniawan, Y. (2017). Penerapan Three-tier Test Untuk Identifikasi Kuanititas Siswa yang Miskonsepsi pada Materi Magnet. Jurnal Ilmu Pendidikan Fisika, 2(1), 11.

Sugiyono. (2015). Metode Penelitian Pendidikan Pendekatan Kuantitatif, Kualitatif, dan $R \& D$. Bandung: Alfabeta.

Sujarwo, S. (2014). Hubungan Antara Efikasi Diri dengan Kecemasan
Belajar Matematika pada Siswa IPS Kelas I SMA Karya Ibu Palembang. Jurnal Ilmiah PSYCHE, 8(1), 63.

Sujarwo, S., Psikologi, F., \& Bina, U. (n.d.). Hubungan antara efikasi diri dengan kecemasan belajar matematika pada siswa ips kelas xi sma karya ibu palembang, 61-71.

Sunaryo, Y. (2017). Pengukuran Self Efficacy Siswa dalam Pembelajaran Matematika di MTSN 2 Ciamis. Jurnal Teori Dan Riset Matematika (TEOREMA), 1(2), 40.

Yuliarti, R., Khanafi, S., \& Putra, N. M. D. (2016). Penerapan Strategi Pembelajaran Generative Learning Berbantukan Scientist's Card untuk Meningkatkan Self Efficacy Siswa Kelas VIII SMP. Jurnal Pendidikan Fisika Indonesia (JPFI), 12(1), 27. https://doi.org/10.15294/jpfi 